\title{
O trabalho de campo na formação do pensamento e do raciocínio geográfico do professor ${ }^{i}$
}

\author{
Fieldwork in the formation of the teacher's thinking and geographic \\ reasoning
}

\section{Carina Copatti}

\section{RESUMO}

O objetivo deste artigo é debater sobre a importância do trabalho de campo na formação do pensamento e do raciocínio do professor de Geografia e utilizar uma experiência vivenciada no Chile para abordar alguns aspectos que contribuem para o processo de formação. Como questão central visa responder: de que maneira, pela experiência de trabalho de campo, pode-se construir o pensamento e o raciocínio geográfico do professor, contribuindo à formação profissional e à educação geográfica? Para tanto, a pesquisa teórico-bibliográfica, com base em autores que abordam temas como pensamento geográfico, formação de professores e trabalho de campo, compõe a tessitura da reflexão entrecortada com uma experiência de trabalho de campo realizada na região Los Lagos - Chile (2018). As experiências de trabalho de campo, quando bem organizadas e fundamentadas, contribuem à formação e para que o professor realize a leitura do espaço, de seus elementos e das relações que nele são construídas e reconstruídas continuamente, tendo condições de contribuir para a educação geográfica, processo essencial no ensino de geografia.

Palavras-chave: Formação de professores; Pensamento geográfico de professor; Raciocínio geográfico; Trabalho de campo

\section{ABSTRACT}

The aim of this article is to discuss the importance of fieldwork in the formation of thinking and reasoning of the teacher of geography and to use an experience experienced in Chile to address some aspects that contribute to the formation process. The central question is to answer: in what way, by the experience of fieldwork, can we construct the thought and the geographic reasoning of the teacher, contributing to vocational training and geographic education? To this end, the theoretical-bibliographic research, based on authors addressing topics such as geographic thinking, teacher training and fieldwork, makes up the tessiture of the intercropped reflection with a field work experience carried out in the region Los Lagos - Chile (2018). The field work experiences, when well organized and grounded, contribute to the formation and that the teacher performs the reading of the space, its elements and the relationships that are built and reconstructed continuously, having conditions of Contribute to geographic education, an essential process in the teaching of geography.

Keywords: Teacher training; Geographic thinking of teacher; Geographic reasoning; Field work 


\section{INTRODUÇÃO}

O trabalho de campo constitui-se como uma metodologia indispensável à formação de professores de geografia, tendo em vista que alia o conhecimento da ciência geográfica, estudado no contexto acadêmico, com os elementos presentes em um recorte espacial investigado na prática, o que contribui para interpretar de forma mais ampla as dinâmicas da sociedade em interação com a natureza.

Na formação de professores de geografia, essa metodologia é essencial no intuito de contribuir à formação dos acadêmicos, futuros professores, para a leitura do espaço e desenvolver o raciocínio geográfico, contribuindo para aliar a teoria abordada em sala de aula e a prática vivenciada, como subsídios para a atuação docente, posteriormente.

Diante disso, o objetivo, neste artigo, é debater sobre a importância do trabalho de campo na formação do pensamento e do raciocínio do professor de geografia e utilizar uma experiência vivenciada no Chile para abordar aspectos que contribuem com o processo de formação. Esse processo de formação tende a contribuir para que o acadêmico realize a leitura do espaço, de seus elementos e das relações que nele são construídas e reconstruídas continuamente. Perpassa essa reflexão, como questão central: de que maneira, pela experiência de trabalho de campo, pode-se construir o pensamento e o raciocínio geográfico do professor, contribuindo à formação profissional e à educação geográfica?

Compreende-se que essa metodologia possibilita ampliar o pensamento do professor, contribuindo para a construção de um arcabouço teórico-conceitual e procedimental que possibilite realizar análises geográficas.

A reflexão proposta alia uma abordagem de cunho teórico-bibliográfico construída com base em autores que debatem sobre formação de professores, pensamento geográfico, educação geográfica (CASTELLAR, 2005; CALLAI, 2016; 
GARRIDO, 2005) e trabalho de campo (MARTIJA E SILVA, 2013), com uma experiência empírica de trabalho de campo realizada na região Los Lagos, Chile (2018). E evidencia aspectos que envolvem a construção do pensamento do professor, o raciocínio e a análise geográfica, na interlocução entre teoria e prática.

As aprendizagens obtidas na experiência de estudos no Chile foram possíveis através do intercâmbio fruto do convênio entre o Programa de PósGraduação em Educação nas Ciências e a Universidade Acadêmica de Humanismo Cristiano-UAHC, mediado na Unijuí pela professora Helena C. Callai e na UAHC Chile pelo professor Marcelo Garrido Pereira.

Teve como finalidade trocar experiências de pesquisa com professores e acadêmicos do curso de geografia e compreender, pela metodologia de trabalho de campo, avanços nas pesquisas e na formação em geografia no Chile. As atividades foram desenvolvidas na primeira quinzena do mês de setembroii de 2018 e proporcionaram o (re)pensar de práticas de ensino e a retomada de conhecimentos estudados durante a graduação em geografia.

No decorrer do artigo, num primeiro momento, debate-se sobre a formação de professores considerando o desenvolvimento de um pensamento geográfico e um modo de raciocínio geográfico. Em seguida, busca-se nos aportes metodológicos do trabalho de campo tecer reflexões sobre a formação do conhecimento do professor no intuito de conduzir a análises geográficas e, por meio da experiência a campo, refletir sobre a formação em geografia construindo aportes para a educação geográfica, compreendida, a partir de Castellar (2005), como um modo de superar aprendizagens repetitivas e arbitrárias, adotando práticas de ensino que invistam nas seguintes habilidades: análise, interpretação e aplicação em situações práticas. 


\section{FORMAÇÃO DE PROFESSORES E O DESENVOLVIMENTO DO PENSAMENTO E DO RACIOCÍNIO GEOGRÁFICO}

No cotidiano, inúmeras vezes, lemos ou ouvimos sobre diferentes lugares, entramos em contato com situações que nos são estranhas e com notícias de acontecimentos que ocorrem em espaços distantes dos quais habitamos. Enquanto professores, em sala de aula, precisamos trabalhar essas informações relacionando-as com os conteúdos e conceitos da ciência geográfica que, no contexto escolar, ganham novos significados frente àquelas expressões curiosas que nos chegam da maioria dos estudantes. Esse processo desafia o professor a utilizar-se de um emaranhado de conhecimentos e de informações que precisam estar bem consolidadas.

Essas estruturas compõem o que se denomina como pensamento geográfico do professor (COPATTI, 2019), constituído a partir do pensamento geográfico construído na evolução da geografia como ciência e área do conhecimento e leva em conta, também, outros elementos. Estes aspectos contribuem para que o professor consiga tanto pensar estratégias de como ensinar geografia a partir da ciência, quanto nas formas de abordagem da geografia numa dimensão pedagógica, a partir de um processo em que conduza os estudantes a interpretar o mundo da vida, sua realidade cotidiana e as situações socioespaciais sob o viés geográfico.

Estas questões perpassam, além do pensamento geográfico do professor, pelo raciocínio geográfico que o professor desenvolve ao longo da sua formação e que insere no processo de ensino e aprendizagem que propõe. Para isso, é preciso que, na formação destes profissionais, essa construção seja realizada de maneira a possibilitar o desenvolvimento da capacidade de tecer a trama das relações que constituem a ciência geográfica. Formar professores envolve, portanto, a dimensão teórica e pedagógica em constante relação. 
O pensamento geográfico foi constituído no decorrer da evolução da geografia, muito além da sua especificidade enquanto ciência. Conforme Callai (2016), o pensamento geográfico requer que se pense a partir da dimensão espacial do espaço construído. Para tanto, é preciso ter conceitos próprios, e esses conceitos fornecem ferramentas intelectuais para fazer a geografia e sustentar esse modo de pensamento. Assim, o pensamento geográfico de professor comporta aspectos desse pensamento específico da geografia construído com embasamento científico e trabalhado na academia a partir de um recorte dessa ciência delineada ainda no decorrer do século XVIII e consolidada no século seguinte.

O raciocínio geográfico se refere ao modo de pensar e construir estratégias de pensamento que se relacionem ao uso dos aportes geográficos, que são os conceitos, as categorias, os princípios geográficos e, também, a linguagem geográfica e cartográfica, utilizando a escala de análise para compor esse processo de raciocinar geograficamente. Cavalcanti (2008) compreende o raciocínio geográfico pelo desenvolvimento dos modos do pensamento geográfico e pela internalização de métodos e de procedimentos para captar a realidade, tendo consciência de sua espacialidade.

Pensamento e raciocínio geográfico, relacionados, possibilitam ao professor, sob inúmeras estratégias que seu pensamento geográfico comporta, construir modos de analisar geograficamente $e$, ainda, modos de ensinar que contribuam para que os alunos realizem análises geográficas. Isso requer que considere as inúmeras possibilidades de abordar a geografia e de construir conhecimentos a respeito dos fatos/fenômenos em estudo.

O desenvolvimento do pensamento geográfico é um processo importante na formação docente, uma vez que possibilita que construam relações, seja na perspectiva da escala de análise (não apenas do local para o global), e considerando a relação sociedade-natureza em toda a sua estrutura, tendo em 
vista que, geralmente na formação de professores, pela fragmentação que ocorre na ciência geográfica, há dificuldades em tecer estas relações.

Considerando estas dificuldades é necessário, então, pensar sobre quais propostas metodológicas poderiam contribuir para que a construção teórica esteja imbricada na prática docente. Assim, a escolha de metodologias coerentes à leitura do espaço na formação de professores é fundamental. Tendo em vista que são diversas as possibilidades para que se realizem análises geográficas, definiu-se como percurso o trabalho de campo como uma possibilidade de desenvolver, no professor, aportes para a formação do seu próprio pensar e raciocinar geográfico, essenciais para ensinar geografia na escola.

Nessa perspectiva, inicialmente, debate-se sobre a estrutura que envolve o trabalho de campo e sua contribuição à construção do raciocínio geográfico.

\section{O TRABALHO DE CAMPO NA CONSTRUÇÃO DE RACIOCÍNIOS E ANÁLISES}

\section{GEOGRÁFICAS}

O trabalho de campo constitui-se como uma metodologia indispensável na formação de professores por relacionar o conhecimento da ciência geográfica e os elementos a serem observados, in loco, em um determinado espaço. Na formação de professores de geografia, essa metodologia é essencial para desenvolver o raciocínio espacial, contribuindo para aliar a teoria abordada em sala de aula e a prática vivenciada como subsídios para a atuação docente.

O roteiro de estudo de campo é construído a partir da perspectiva de conhecer e compreender as dinâmicas físicas, econômicas e/ou culturais, de acordo com a finalidade estipulada pelo(os) professor(res). Esse roteiro pode contemplar desde o deslocamento entre determinados lugares ou especificamente em determinada área a ser estudada. Porém, não basta definir o roteiro de estudo, uma vez que requer, ainda, um criterioso planejamento dos trajetos, dos deslocamentos e da finalidade de cada etapa. 
Na definição do trabalho de campo, as atividades precisam ser previamente sistematizadas pelos professores e expostas aos acadêmicos participantes, visto que o conhecimento dos objetivos e as possíveis adaptações a serem feitas precisam ser considerados na construção de um processo educativo que tenha significado e esteja claro aos estudantes.

No desenvolvimento do trabalho de campo, uma das pretensões é contribuir à construção do olhar geográfico visando aperfeiçoar nos acadêmicos a sua inserção na pesquisa, estimulando-os a analisarem o espaço em estudo e a utilizar-se de técnicas de pesquisa adequadas a tal atividade. Para tanto, a metodologia adotada para realizar a interação entre a teoria abordada nos componentes curriculares e o roteiro de campo são diversas, variando tanto em relação ao processo de observação e as anotações em diários de campo, quanto com relação a possível aplicação de questionários e realização de entrevistas; ainda, com relação às produções orientadas de significados e de outras tantas possibilidades que podem ser tomadas pelo professor a partir de um planejamento prévio, ou definidas e redefinidas com a participação dos estudantes.

No decorrer do trabalho de campo, em períodos curtos (um ou dois dias) ou longos (vários dias, uma semana...), são produzidos diversos dados e informações por meio de documentos, registros fotográficos, materiais impressos, pela análise de mapas, dentre outros processos que, posteriormente, colaboram na construção dos relatórios de campo, solicitados em distintos componentes curriculares como uma forma de avaliação das atividades realizadas. Servem, principalmente, para o exercício reflexivo do processo de construir um modo de pensar sistematizado a respeito de determinado tema em um contexto e um recorte espacial.

O contato com a realidade em estudo permite aos acadêmicos ampliar as possibilidades de aprendizagem e, por consequência, favorece sua formação enquanto geógrafos ou professores de geografia; isso permite distintos modos 
de trabalhar essa ciência e de raciocinar sobre ela com base nos aportes teóricoconceituais, nos recursos metodológicos, na escala de análise, dentre outros elementos que precisam ser levados em conta ao construir interpretações sobre aquilo que se pesquisa a campo.

A partir da metodologia utilizada, é possível produzir diferentes dados e, ainda, servir como suporte para que os acadêmicos, quando professores, utilizem-se destas para propor atividades de campo com seus alunos. Nesse processo, a observação in loco facilita a compreensão dos estudantes em relação à complexidade dos fenômenos e conceitos que são foco de estudos da geografia. Essa construção é processual e tem importância fundamental na formação inicial de professores, momento em que as bases teóricas para isso são construídas, embora este seja um processo aprimorado no decorrer do trabalho docente.

Conforme Callai (1999, p. 12), compreender a realidade por meio da geografia significa conseguir manejar os conceitos básicos e os instrumentos adequados para fazer a investigação e a exposição dos seus resultados. Os conceitos de espaço geográfico, lugar, paisagem, território, região constituem-se como basilares à análise geográfica. Essa análise também envolve utilizar categorias e princípios geográficos, os quais contribuem à interpretação sob o aporte dessa ciência.

A formação dos professores de geografia precisa levar em conta o desenvolvimento do pensamento num processo em que se construam relações, tanto na perspectiva da escala de análise (não apenas do local para o global), quanto pela interação sociedade-natureza em toda a sua estrutura, tendo em vista que, geralmente, pela fragmentação que ocorre na ciência geográfica há dificuldades em tecer estas relações. Diante destas dificuldades, é necessário pensar sobre que propostas metodológicas poderiam contribuir para que a construção teórica esteja imbricada na prática de trabalho do professor. Assim, a 
escolha de metodologias coerentes à leitura do espaço pelos professores em formação é fundamental.

A metodologia de trabalho de campo pode proporcionar ao acadêmico que entre em contato com diferentes realidades ou situações as quais são trabalhadas na geografia e que precisam de entendimento do professor/geógrafo. Conforme salienta Tomita (1999, p. 13):

\footnotetext{
Dentre várias técnicas utilizadas no ensino de Geografia, considera-se o trabalho de campo, uma atividade de grande importância para a compreensão e leitura do espaço, possibilitando o estreitamento da relação entre a teoria e a prática. O alcance de um bom resultado parte de um planejamento criterioso, domínio de conteúdo e da técnica a ser aplicada.
}

Alguns argumentos contribuem no sentido de refletir sobre a importância do trabalho de campo para o desenvolvimento do pensamento geográfico do professor e da capacidade de raciocinar geograficamente, contribuindo, assim, para potencializar uma formação que alie distintos aspectos que constituem ainda desafios no que tange à formação e o ensino da geografia.

1. O trabalho de campo como ferramenta de aproximação entre teoria e realidade: sendo uma atividade prática, o trabalho de campo contribui para a compreensão das teorias estudadas em sala de aula e possibilita que surjam outros elementos a serem debatidos. Nesse processo, torna-se possível, pela prática de campo, aprofundar algumas questões e analisá-las de modo a permitir maior compreensão e aprofundamento do conhecimento da realidade.

2. Praticidade em relação a questões abstratas: esse processo, no estudo de campo, torna possível que o acadêmico vivencie na prática estudos anteriormente feitos a partir de conceitos abstratos, estabelecendo relações teórico-práticas. Outro elemento importante é a análise das características do lugar, estabelecendo análises em diferentes escalas, a fim de ampliar o conhecimento também do lugar próximo, daquilo que é vivido no cotidiano.

Callai (2012, p. 71) salienta que "muitas vezes sabemos coisas do mundo, admiramos paisagens maravilhosas, nos deslumbramos por cidades distantes, 
temos informações de acontecimentos exóticos ou interessantes de vários lugares que nos impressionam, mas não sabemos o que existe e o que está acontecendo no lugar em que vivemos". Nesse sentido, o trabalho de campo é uma proposta que permite aproximação com a realidade de determinado lugar em que diferentes situações podem ser observadas ou vivenciadas pelos acadêmicos no processo de construção do conhecimento.

3. O Trabalho de Campo na multidimensionalidade de experiências: o trabalho de campo fomenta outras abordagens e possibilidades de leitura do espaço. Permite a análise de elementos físicos, econômicos, culturais, dentre outros que, em maior ou menor ênfase, dependendo do tema do trabalho de campo, se sobrepõe aos demais, mas que, num contexto geral, se relacionam e contribuem para que o futuro professor desenvolva um olhar acurado em relação às dinâmicas possíveis na construção e transformação do espaço pelos grupos que ali vivem. Consideramos também a possibilidade de conceber a geografia enquanto uma ciência da percepção, interagindo com a realidade e a partir dela construir significados. De acordo com Corrêa (1996), o campo é um meio no qual o geógrafo aprende a ver, analisar e refletir sobre o infindável movimento de transformação que o homem realiza no espaço, é no campo que o aluno/pesquisador poderá perceber todo o dinamismo do espaço.

4. O trabalho de campo como provocador-inquietador na relação com o espaço: nesse processo, o espaço é pensado para determinado uso, de acordo com as concepções e necessidades de determinados grupos sociais nele estabelecidos. Essa relação perpassa pela necessidade de interpretar cuidadosamente o olhar lançado sobre o espaço, a sociedade que nele se estabeleceu, seus traços culturais, as formas de trabalho evidenciadas ali, as interferências que os grupos realizam, possibilitando compreender as dinâmicas espaço-temporais que perpassam o espaço em estudo.

5. O trabalho de campo enquanto espaço unificador: essa metodologia é capaz de ir além da fragmentação da geografia em física e humana. Suertegaray 
(2005, p. 43), traz a experiência de Reclus, que, em termos metodológicos, não aceitava a clássica dicotomia entre geografia física e geografia humana, preferindo ressaltar sua unidade em favor de uma "Geografia Social", colocando pioneiramente a geografia como instrumento de transformação. Essa perspectiva precisa ser considerada ao analisar e compreender as relações entre sociedade e natureza.

6. O trabalho de campo como meio para a produção de conhecimento: a partir das análises possíveis na prática de campo, se tem, como resultado, dados empíricos que, quando relacionados às teorias abordadas em sala de aula, tornam possível a construção de análises e de conclusões a respeito desse processo. Surgem também dúvidas que podem ser discutidas junto aos professores e colegas, a fim de ampliar o conhecimento e a compreensão do processo de leitura e análise do espaço em estudo.

Isto posto, o trabalho de campo, quando bem estruturado e organizado, traz significações importantes à formação do pensamento e do raciocínio do professor de geografia, uma vez que diversos estudos são realizados e diferentes conclusões podem ser tomadas, tendo por base o foco do trabalho. É nesse processo que o professor formador tem papel fundamental, visto que é ele que articula diferentes elementos, instiga a análise, estimula que o estudante vá além do que é visível num primeiro olhar. Permite experienciar por si e não apenas pelas descrições possíveis em fotografias e textos de livros, artigos e revistas, visualizar, analisar, perceber as características que fazem com que determinado espaço tenha certas características e elementos que não estão presentes em outros.

O olhar sobre o espaço possibilita a sensibilização para com os lugares de vivência e outros espaços sociais e culturais em que a educação geográfica pode ser realizada. Nesse processo de leitura e significação do espaço por meio de trabalhos de campo, é possível definir aspectos a serem considerados em cada 
etapa e em cada local a ser visitado, tomando por base os conceitos e as relações teóricas a serem retomadas ao percorrer o trajeto.

A experiência vivenciada no Chile, em 2018, abordada a seguir, contribui para o debate sobre o processo de constituição do pensamento e do raciocínio geográfico que são essenciais à docência e à proposição de uma educação geográfica no ensino escolar de geografia.

\section{A FORMAÇÃO DO PROFESSOR DE GEOGRAFIA PELO TRABALHO DE CAMPO: UMA EXPERIÊNCIA PRÁTICA NA REGIÃO LOS LAGOS - CHILE}

O trabalho de campo, no contexto da Universidade Academia de Humanismo Cristiano - UAHC, constitui uma das etapas de uma disciplina acadêmica obrigatória no curso de graduação em Geografia - bacharelado, na qual os estudantes participam do planejamento da atividade e conduzem, nesta etapa, o processo de análise geográfica de modo prático, interpretando e compreendendo determinado recorte espacial sob aportes teóricos.

A etapa inicial consiste em atividades em laboratório e a definição de materiais que contribuam ao trabalho de campo e que sejam de fonte bibliográfica e documental. Requer, nessa etapa, a delimitação da área de estudo, descrevê-la e caracterizá-la, construindo todo o planejamento do que pesquisar. E tem como elemento estruturante a construção de um Levantamento Integrado de Variáveis - LIViii, que sustenta a pesquisa empírica, mas que pode, em alguns casos, sofrer modificações ao longo da investigação.

A pesquisa empírica no trabalho de campo constitui a fase posterior, organizada e sistematizada com base nos debates e nas questões apontadas como objetivo de investigação. Desse modo, pode-se esclarecer a singularidade que assume um trabalho de campo. Martija e Silva (2013, p. 151), afirmam que "la salida a terreno busca ir a un lugar para aplicar conocimientos y 'ver' de primera fuente lo que en los textos de estudio se ha trabajado. Suele estar enfocada en la observación. El trabajo de campo, implica un trabajo de generación y procesamiento de información". 
O trabalho de campo envolve, assim, a observação, a investigação, a geração de informações, as análises e o processamento destas, configurando novos conhecimentos que oportunizam a complexificação do pensamento dos futuros professores e da capacidade de raciocinar geograficamente; pode-se, assim, construir análises a partir de sua própria organização de pesquisa e sistematização de informações à luz do aporte da ciência geográfica.

Para desenvolver o trabalho de campo foram formados três grupos, cada um deles composto por cinco membros. Os temas de pesquisa foram definidos da seguinte forma: 1. Risco de remoção em massa (Ensenada); 2. Expansão urbana e desenvolvimento turístico (Frutillar); 3. Modificação de serviços ecossistêmicos na borda do lago Llanquihue (municipalidade de Puerto Octay). Após a definição, os grupos deveriam planejar as etapas da pesquisa: definir a problemática, os aportes metodológicos ao trabalho de campo, os instrumentos e recursos necessários. Deveriam, também, caracterizar a região em aspectos físico-naturais e humanosociais e definir os conceitos de sustentação teórica a constar no LIV. Assim, antes da saída a campo foi necessário seguir os seguintes critérios: 1. Definição do enfoque epistemológico; 2. Definição do tipo de pesquisa; 3. Definição da unidade de estudo/análise; 4. Definição da amostra segundo critérios teóricos e estratégicos (recursos a utilizar); 5. Definição de técnicas de levantamento e tratamento de dados.

As atividades junto ao grupo de estudantes responsável por pesquisar as atividades referentes ao uso do solo e modificações de serviços ecossistêmicos "en la rivera del lago Llanquihue", posteriormente denominado "práticas na borda lacustre que afetam ao suporte ecossistêmico do lago Llanquihue", possibilitou vivenciar um trabalho de organização em equipe, o que exigiu bastante diálogo e a distribuiç̧ão de tarefas; e ainda, o cumprimento destas em tempos e locais predefinidos, porém, com dificuldades, haja vista que houveram trechos de difícil acesso tanto em termos de deslocamento quanto no sentido do acesso às pessoas para realização de entrevistas. O planejamento do tempo se constitui elemento essencial a ser considerado em atividades futuras, no intuito de obter maior êxito na tarefa de pesquisa de campo. 
Figura 1- Lago Llanquihue. Distribuição cronológica da ocupação. Plano de Emilio Held. Sourcee: Liga Chileno-Alemana, Santiago. Destaque para o setor norte (Vmunicipalidade Puerto octay).

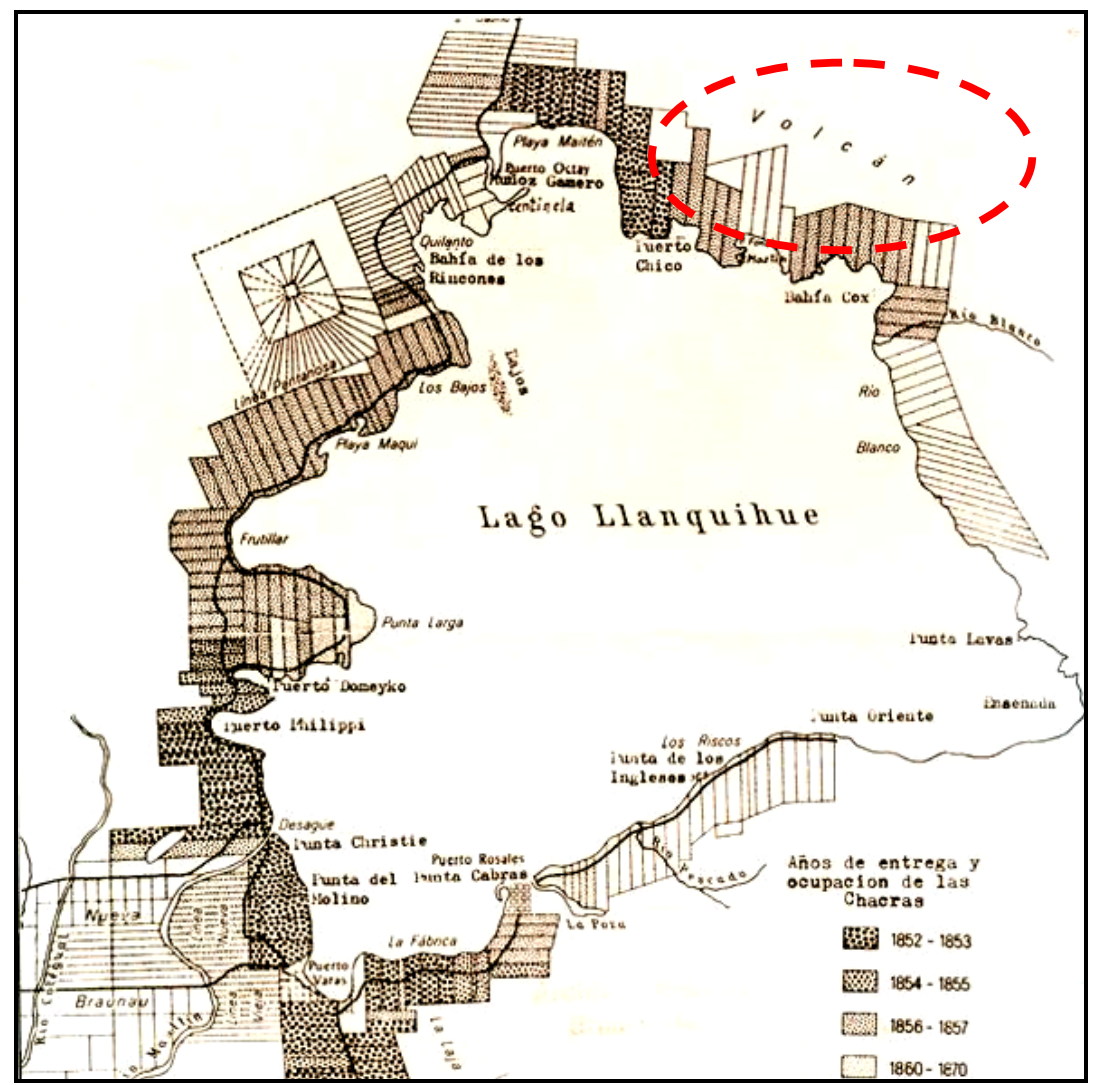

Fonte: Conselho Nacional De La Cultura Y Las Artes. (Pesquisado em setembro/2018).

No primeiro dia, as atividades envolveram o deslocamento na área urbana de Puerto Octay, levando em conta aspectos naturais de solo, fauna, flora e as dinâmicas que envolvem o uso do solo na borda do lago Llanquiheu, que possui uma área de $860 \mathrm{~km}^{2}$. No entanto, o recorte espacial de pesquisa foi delimitado na extensão da borda norte do lago, nos limites da municipalidade de Puerto Octay. Porém, foram consideradas não apenas as atividades desenvolvidas estritamente na borda do lago, mas as dinâmicas que envolvem a população que habita essa municipalidade em uma faixa maior, não definida antecipadamente, o que dificultou o início da atividade de investigação do grupo. Diante disso, foi salientada pelo professor coordenador, a necessidade de delimitar com exatidão a extensão do fenômeno a ser analisado, caracterizá-lo e descrevê-lo, como uma das necessidades iniciais na atividade de campo. 
A área de estudo deste grupo pode ser observada na figura 1, no trecho destacado no círculo.

A reunião do grupo referente à sistematização das etapas resultou na seguinte organização para a investigação:

\section{Quadro 1 - Procedimentos de investigação}

\begin{tabular}{|c|c|c|}
\hline & $\begin{array}{l}\text { Estudo teórico de } \\
\text { autores }\end{array}$ & $\begin{array}{l}\text { apa prévia, realizada a partir da consulta a autores e obras } \\
\text { ara definir termos e conceitos essenciais a um trabalho de } \\
\text { mpo. }\end{array}$ \\
\hline & $\begin{array}{l}\text { Definição } \\
\text { metodológica para } \\
\text { produção de dados }\end{array}$ & $\begin{array}{l}\text { Procedimentos de organização das etapas de pesquisa e } \\
\text { produção dos dados, definindo o uso de estudos de gabinete } \\
\text { (plano regulador, mapas, imagens de satélite) e estudos a } \\
\text { campo (observação da estruturada, registros em diário de } \\
\text { campo com apoio de fotografias, entrevistas estruturadas, } \\
\text { croquis cartográficos). }\end{array}$ \\
\hline 3. & $\begin{array}{l}\text { Definição do tema de } \\
\text { investigação do grupo }\end{array}$ & $\begin{array}{l}\text { Definido como "ecosistemas y uso del suelo en la rivera del } \\
\text { lago Llanquihue". }\end{array}$ \\
\hline 4. & $\begin{array}{l}\text { Definição do objetivo } \\
\text { da investigação a } \\
\text { campo }\end{array}$ & borda do Lago Llanquihue. \\
\hline . & $\begin{array}{l}\text { Definição do } \\
\text { problema a investigar: }\end{array}$ & $\begin{array}{l}\text { "Prácticas en la rivera del lago que afectan el suporte } \\
\text { ecosistémico do lago Llanquihue". }\end{array}$ \\
\hline 5. & $\begin{array}{l}\text { Demarcação da área } \\
\text { de investigação a } \\
\text { campo }\end{array}$ & $\begin{array}{l}\text { Borda ribeirinha do lago Llanquihue - região Los Lagos - } \\
\text { extensão longitudinal e definição de largura. (Área de borda } \\
\text { na municipalidade de Puerto Octay: Puerto Fonck, Puerto } \\
\text { Oclock, Playa Maiten). }\end{array}$ \\
\hline 7. & $\begin{array}{l}\text { Construção do LIV e } \\
\text { definição das } \\
\text { categorias de análise }\end{array}$ & $\begin{array}{l}\text { Uso do espaço social, comunitário, público, privado; } \\
\text { Uso atual e uso potencial. }\end{array}$ \\
\hline & $\begin{array}{l}\text { Procedimentos de } \\
\text { análise dos dados e } \\
\text { construção de } \\
\text { relatório final }\end{array}$ & $\begin{array}{l}\text { Primeira etapa desenvolvida durante a atividade a campo, } \\
\text { todas as noites após a conclusão diária das tarefas; } \\
\text { Segunda etapa a ser construída após o trabalho de campo, } \\
\text { em tempo delimitado pelo professor proponente. }\end{array}$ \\
\hline
\end{tabular}

Fonte: a autora, 2019. 
As atividades foram realizadas em três dias, constituídas por análises de terreno, entrevistas com moradores, observações de paisagens, registros em diário de campo, fotografias e filmagens. As entrevistas contaram com "informantes clave", que foram: 1) Bombeiros: (entrevista a um bombeiro): a) Problemas sociais em caso de emergência na borda do lago; b) Existência de registros destes eventos; c) Existência de planos de prevenção e educação. 2) Serviços de saúde (entrevista com uma enfermeira): a) Atenção de problemas de saúde relacionados com a borda do lago; b) Existência de registros destas enfermidades; c) Existência de campanhas de prevenção. 3) Entrevistas com moradores (residentes ou trabalhadores sendo um total de 6 pessoas). Como critérios deveriam viver ou trabalhar na borda do lago, tendo idade acima de 18 anos. As perguntas foram: A) Vive ou trabalha nessa área e há quanto tempo? B) Como é o uso do solo na área próxima ao lago? C) São gerados resíduos na borda do lago? D) Há problemáticas na borda do lago? E) Existem associações que se vinculam a essa área? F) Como você percebe o uso "de la rivera del lago" a nível municipal? G) Há algum plano de conservação dessa área? H) Que práticas são necessárias para melhorar o uso de la rivera lacustre? I) Existem bens patrimoniais e/ou culturais associados à borda do lago? J) Que tipos de relações estabelece com o lugar?

Das observações e entrevistas resultou a análise dos dados obtidos, redefinição do LIV, conclusões do trabalho de campo com elementos sobre as observações realizadas, as experiências obtidas e, principalmente, percebendo a necessidade de um processo de pesquisa mais sistemático e bem estruturado, visto que é um processo essencial ao trabalho tanto dos professores de geografia quanto dos geógrafos. Nesse sentido, o diálogo em grupo e o processo de tomada de decisões se constituíram como elemento importante na construção da autonomia dos estudantes e na construção dos conhecimentos, aliando-os às novas experiências a campo. 


\section{DESDOBRAMENTOS DO TRABALHO DE CAMPO: ASPECTOS DA ANÁLISE DA} BORDA LACUSTRE DO LAGO LLANQUIHUE

A estrutura atual do espaço observado no norte do lago é oriunda do processo de ocupação das terras e da colonização das áreas da região e do entorno, principalmente por imigrantes de origem alemã. A partir dos relatos e das análises realizadas, percebe-se que ocorreu, neste setor, um processo de loteamento e de transformação no modo de uso do solo e das práticas desenvolvidas no entorno do lago, a partir da colonização alemã. Tanto a expansão das atividades ligadas ao campo, quanto das atividades urbanas, anos depois, contribuíram para transformar o espaço e, na relação com a natureza, construir distintos processos socioespaciais ali configurados.

Os elementos do clima, solo, relevo e vegetação contribuíram para a fixação destes habitantes e, ainda, os elementos da cultura, entrelaçam-se na relação construída no espaço habitado, inicialmente apenas por imigrantes alemães e, na atualidade, por habitantes do país, principalmente de Santiago, e estrangeiros que se deslocam para a região.

Há, na atualidade, outros usos da borda do lago e relações diferentes daquelas mantidas no passado. Anteriormente, havia maior concentração de terras sob domínio do governo que, pela dificuldade de acesso aos terrenos próximos ao lago e característico de toda a região, não tinha condições de administrar toda a extensão. É possível perceber, pela análise documental realizada a partir de investigação na biblioteca municipal, que havia menor valorização das terras e do lago, o que mudou gradativamente em meados do século XX, contribuindo para ampliar o povoamento da municipalidade, aumentando o valor das terras a partir da expansão do espaço destinado, dentre outros usos, ao turismo e às atividades agropecuárias em terras férteis da região.

A ocupação da região e especificamente do lago Llanquihue teve mudanças principalmente na segunda metade do século XX e início do século XXI de modo mais 
efetivo quando foram ampliadas as vias de acesso, pavimentadas e não pavimentadas, diminuindo o uso do lago para transporte de produtos e deslocamento de pessoas. Isso se efetiva, em grande medida, pelos avanços tecnológicos que permitem mais investimentos em rodovias e nas atividades turísticas, incentivada também pela expansão do processo de globalização que expande os fluxos de turistas à região, na atualidade.

Figuras 2 - uso do solo na borda do lago no passado a partir do recorte espacial de Puerto Octay.

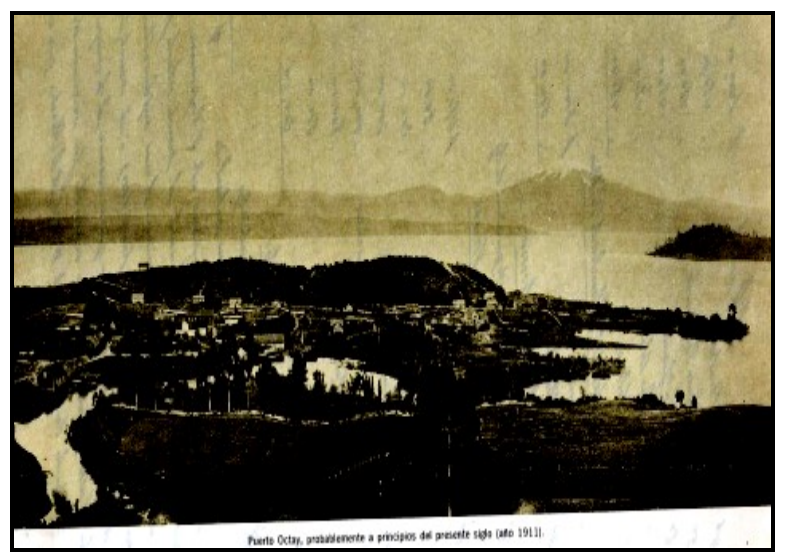

Fonte: Winkler, 1986.

Pelo contato com a população local, na venda de produtos artesanais próximo ao lago, em um restaurante e em uma pequena venda na área central da cidade, foi possível compreender que o período mais intenso de fluxo de pessoas é no verão e se concentra principalmente entre atividades de turismo. Há, ainda, comercialização de produtos coloniais oriundos de atividades ligadas ao campo, com a produção leiteira, principalmente, que é típica da região.

Esse processo demanda estudos tanto em relação aos modos de vida locais, da cultura, costumes, tradições que condicionam a vida na região e especificamente nesta municipalidade, quanto em relação aos elementos naturais que definem os ecossistemas lacustres. Estes também são transformados e sofrem influência da população que ali vive e da população que migra anualmente para a região no período de férias, especialmente no verão, impactando estes ecossistemas. 
Figuras 3 e 4 - uso do solo na borda do lago Lanquihue no presente a partir do recorte espacial de Puerto Octay. Uso residencial (fig. 3) e uso comercial (fig. 4).
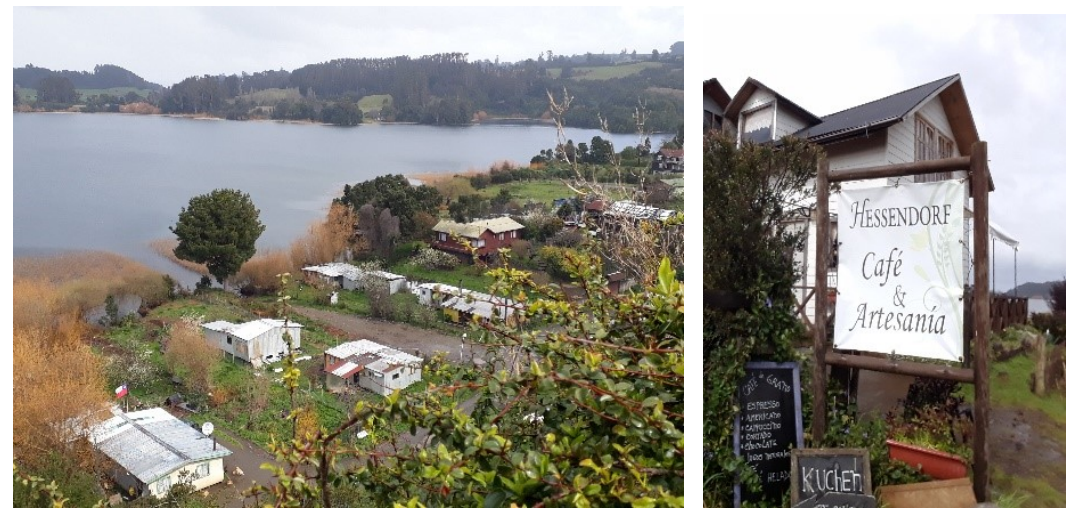

Fonte: Acervo particular da autora (setembro de 2018).

Os serviços ecossistêmicos, definidos pelo grupo como "o conjunto de condições físico-naturais que oferecem condições para a população obter benefícios ou serviços a partir de sua função e estrutura", foi elemento de análise que alicerçou a atividade. Alguns registros fotográficos dessa área ilustram elementos naturais específicos da borda lacustre, como a ocorrência de espécies nativas de vegetação perene, composta por árvores de maior porte, além de arbustos, samambaias e algumas espécies de vegetação mais rasteira, e, também, a presença de aves como o quero-quero.

O uso do solo nesta área mais específica da borda do lago compreende atividades ligadas à agropecuária, turismo, pesca esportiva e extração de lenha e mimbre (vime). Há propriedades privadas localizadas na borda do lago e áreas públicas principalmente nesta área mais urbanizada, destinadas para atividades recreativas e de lazer, porém, com espaços limitados e dotados de pouca infraestrutura para uso da comunidade. Isso se observa pela inexistência de vias de acesso para caminhada com continuidade ao longo do lago, inexistência de placas de atenção referente ao acesso e uso do lago, de espaços de uso público destinados à população local, dentre outros.

Foi possível perceber, por meio das entrevistas, que existem poucas iniciativas em relação ao uso da borda do lago, pois o único projeto desenvolvido 
é relacionado à reciclagem e se destina aos estudantes de escolas da municipalidade, sem relação específica com o uso do lago e com os cuidados referentes à sua conservação.

Figuras 5 e 6 - borda do lago, área de uso público sem infraestrutura (fig. 5) e de uso privado (fig. 6).
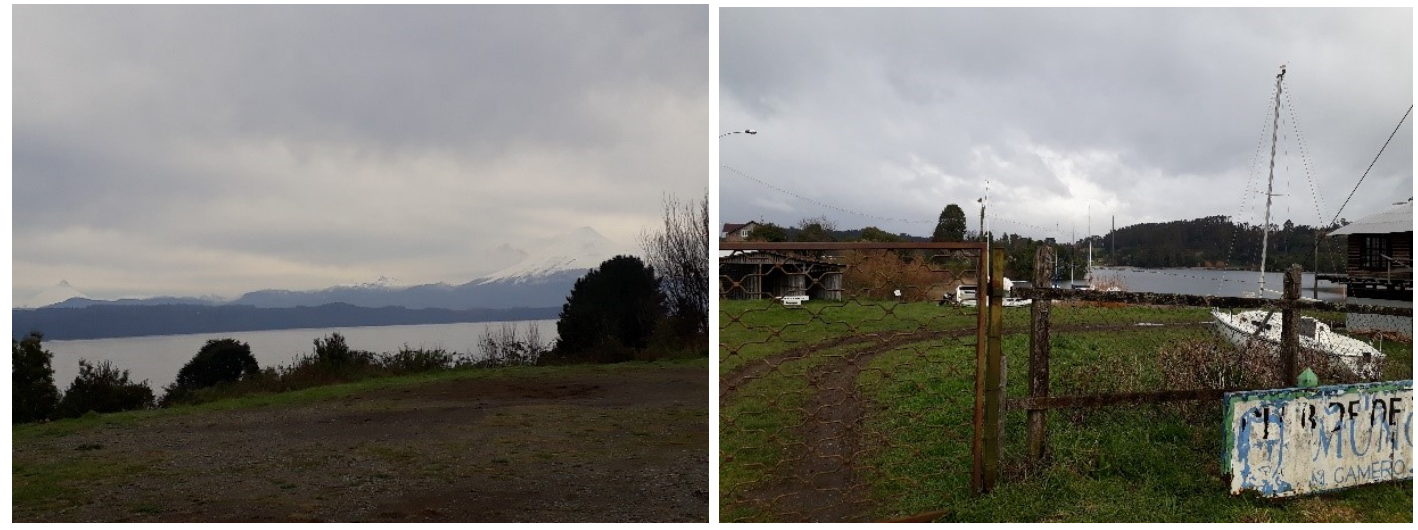

Fonte: Acervo particular da autora (setembro de 2018).

Apesar da existência de placas de advertência em relação ao lixo, em determinadas áreas foram identificados locais em que há a presença de lixo depositado e outros problemas ambientais, como grande quantidade de fumaça proveniente da queima de lenha nas moradias, cujo recurso é quase em sua totalidade retirado na região para calefação. Este problema foi pouco mencionado pelos moradores nas entrevistas, ou seja, não é considerado um problema ambiental para a maioria dos entrevistados, embora pelo menos duas entrevistas destacam a preocupação com a queima de lenha e a retirada de madeira verde de áreas de floresta nativa na borda do lago e regiões próximas.

No dia seguinte, houve a necessidade de retornar a Puerto Octay no intuito de obter mais informações. Foram, então, complementadas as entrevistas com a população local e entrevistas com "informantes clave", não encontrados no dia anterior. E, ainda, obtendo documentos no centro turístico, na biblioteca municipal e no museu municipal da cidade e também o plano regulador com a diretoria de obras. 
Com base no material obtido, foi possível compreender a estrutura de ocupação do entorno do lago na seção norte, onde se localiza a municipalidade de Puerto Octay.

\section{Figura 7 - uso da borda do lago - ocupação residencial e comunitário.}

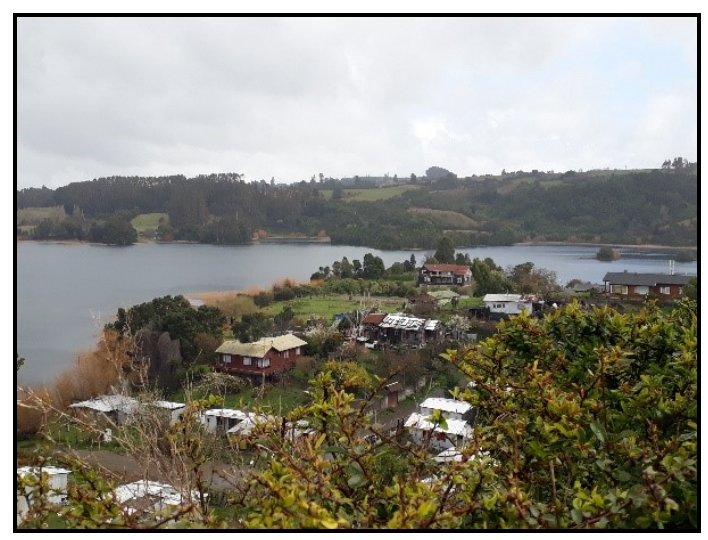

Fonte: Acervo particular da autora (setembro de 2018).

Foi possível perceber que não há um cuidado efetivo da borda do lago e processos de conscientização em relação às possibilidades que ele oferece à população. Isso envolve pensar seu uso consciente e a utilização de recursos obtidos na borda, como o mimbre (vime) e a lenha, que algumas pessoas retiram da mata nativa e, ainda, do reflorestamento de pinus e eucaliptos implementado há alguns anos.

Há, também, a necessidade de refletir sobre as práticas realizadas nesta área e o cuidado com a destinação dos resíduos produzidos nas moradias, empresas, indústrias e no comércio, que interferem diretamente na manutenção da vida no lago Llanquiheu. Observam-se áreas em que há lixo depositado, existe poluição pela proximidade de pequenas unidades fabris e, ainda, pelo uso das bordas do lago pelos moradores que, em sua maioria, não têm rede de esgoto.

A relação com o lugar perpassa pelas interpretações e interferências estabelecidas sob aspectos físico-naturais (práticas de uso do solo, dos recursos hídricos, da fauna e flora, do tipo de relevo, clima e vegetação) e também pelos aspectos sociais que perpassam a vida destas populações que ali estabelecem seus modos de se relacionar e de estabelecer relações com o meio. 
Essas dinâmicas se diferem no espaço urbano de Puerto Octay e na borda do lago em trechos mais distanciados da área central urbanizada, onde há menor ocupação humana e onde se mantém elementos da vegetação nativa e menor ocupação para moradias; embora em algumas áreas de encostas se observem ocupações e o uso de recursos do lago e da sua borda, como a lenha, os pescados e o pasto utilizado para a criação de galináceas e porcos.

Figuras 8 e 9 - uso do solo na borda do lago Lanquihue em Puerto Octay.
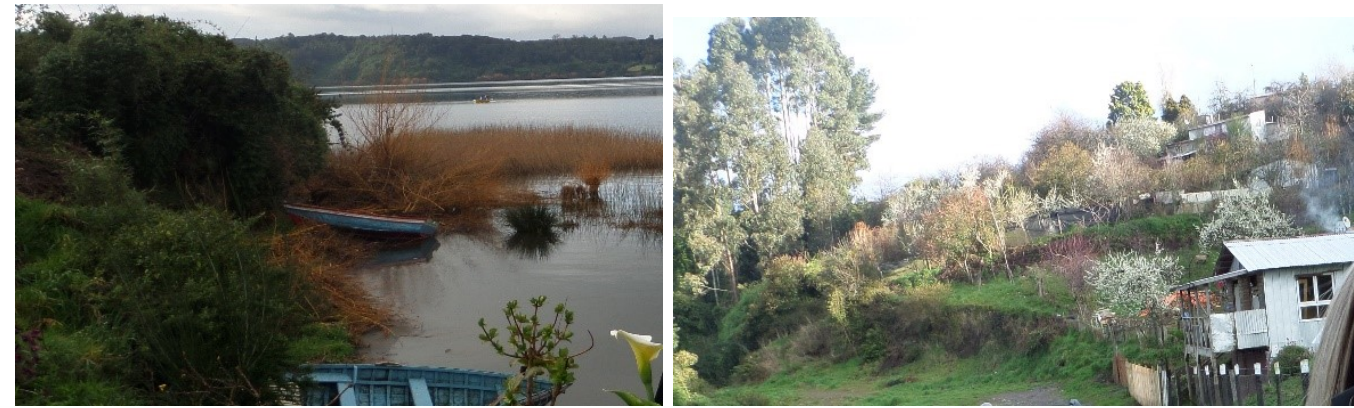

Fonte: Acervo particular da autora (setembro de 2018).

Isso se observa também em Puerto Fonck, onde o uso do solo é destinado a atividades agropecuárias, principalmente leiteira, plantações de cereais e pastagens para o gado, criações de galináceas, uso para turismo em propriedades privadas com aluguéis de casas de veraneio e pesca esportiva. Neste povoado, observa-se a relação entre espaço público e espaço privado, prevalecendo espaços privados com locação de casas, intercalada à atividade agropecuária.

Em outras propriedades, embora próximas à via de tráfego, não há acesso à borda do lago por ser tomada por áreas privadas. Em entrevista, foi percebido que nas pequenas propriedades as práticas se relacionam às atividades de produção familiar, em que se realiza o cultivo de pastagens para alimentar o gado, ovelhas, galináceas, o plantio de verduras, a extração da lenha de florestas nativas e de eucaliptos, para fins principalmente de consumo familiar.

O uso da vegetação para lenha é um dos problemas identificados, além do lixo que é, em alguns trechos, presente na beira do lago. Conforme moradores, não há 
um projeto ou plano continuado de conservação proposto pela municipalidade, sendo apenas uma responsabilidade dos moradores, que nem sempre o fazem.

\section{Figuras 10 e 11 - casa de aluguel para férias na beira do lago (fig. 10) e casa de} moradia (fig. 11).
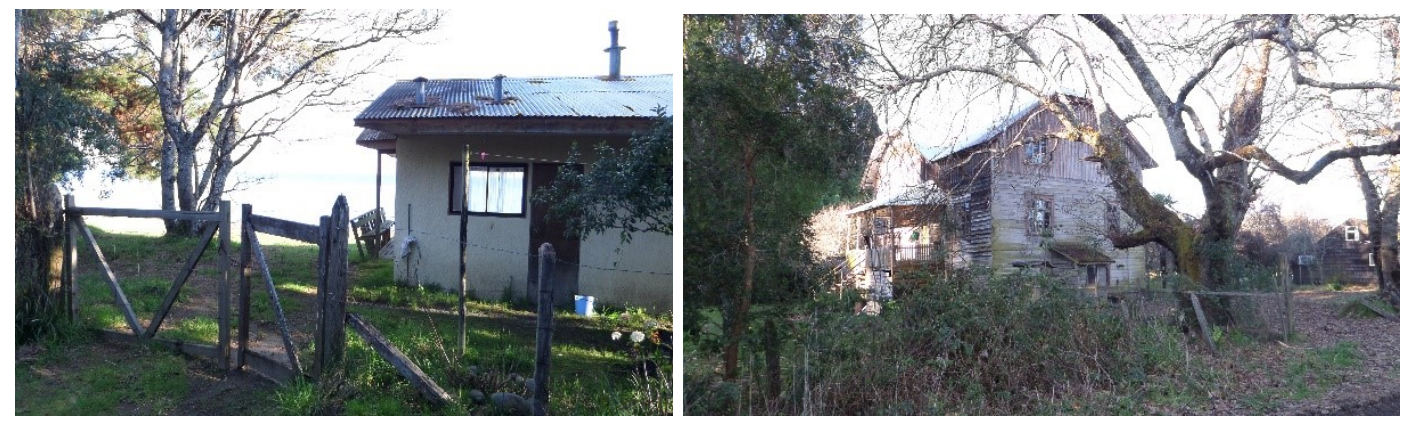

Fonte: Acervo particular da autora (setembro de 2018).

No último dia de trabalho de campo, as atividades foram concentradas, pela manhã, no registro de observação com descrição no diário de campo e sistematização dos registros fotográficos, além de entrevistas em Puerto Oclock, além da visita a uma propriedade privada de grande extensão. À tarde foi realizada uma atividade de observação em Playa Maiten, com registros fotográficos e tentativas de entrevistas, uma vez que naquele local nenhum morador concordou em participar da pesquisa.

Os contrastes entre as paisagens de cada local trazem a dimensão da ocupação do espaço e a definição do território como elemento importante a ser analisado. As propriedades privadas compõem a marca dos locais visitados, uma vez que não se encontra, na beira do lago, espaço de uso público. Mantém-se da via asfáltica até a borda do lago, distante cerca de um quilômetro, áreas de terra privadas cujos donos vivem do uso do solo para produção agropecuária, neste caso alugando as terras para que outros moradores realizem estas atividades; ainda, para fins de turismo, com locação de diversas casas na borda do lago, principalmente no verão e também no inverno, visto que a região comporta além do lago, os vulcões Osorno e Calbuco e os rios Maullín e Petrohue, entremeados à vegetação nativa. 
Figuras 12 e 13 - casa de aluguel para férias na beira do lago (propriedade privada, fig. 12) e paisagem da propriedade onde há gado leiteiro (fig. 13).
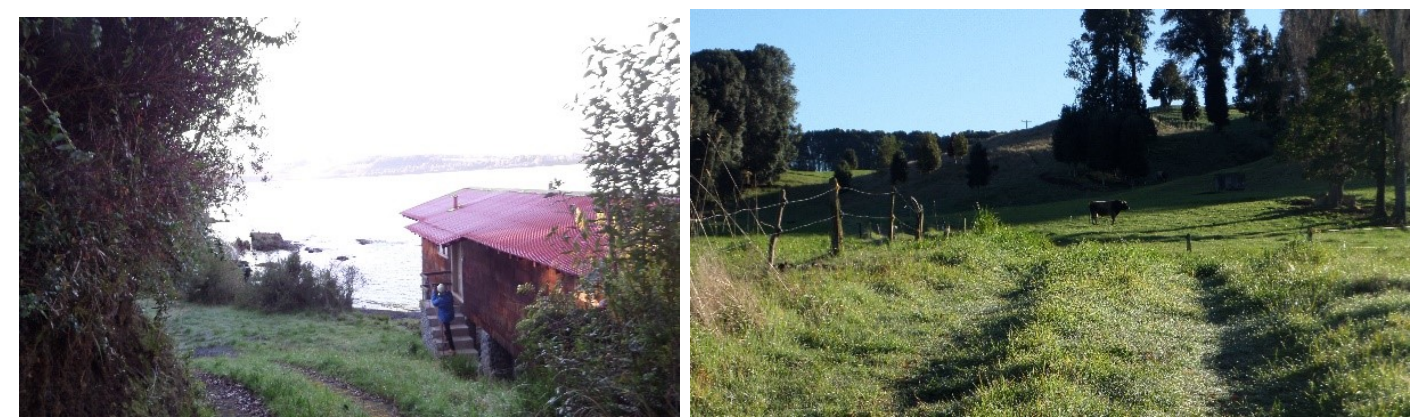

Fonte: Acervo particular da autora (setembro de 2018).

De modo semelhante ao que ocorre em Puerto Oclock, a Playa Maiten também compreende áreas de uso privado, principalmente destinada à moradia, atividade leiteira e turismo na borda do lago. O uso do território remete ao uso que se faz do espaço a partir de estruturas de poder que se impõe sobre determinada área, neste caso, propriedades privadas, cujo acesso é restrito e onde foram encontradas, em vários momentos, seja em Puerto Fonck, Oclock ou Playa Maiten, dificuldades de acesso aos seus habitantes e resistência por parte de alguns moradores em dialogar com os pesquisadores.

Pode-se constatar que os espaços público, de uso comum, têm maior destaque na área urbanizada de Puerto Octay, em determinados espaços bem delimitados. Mas prevalece o uso do território de forma privada, mantendo áreas do entorno do lago destinadas apenas a determinado grupo de pessoas, conforme poder aquisitivo para usufruir dele.

O território, para Haesbaert, enquanto mediação espacial do poder, resulta da interação diferenciada entre as múltiplas dimensões desse poder, desde sua natureza mais estritamente política até seu caráter mais propriamente simbólico, passando pelas relações dentro do chamado poder econômico, indissociáveis da esfera jurídicopolítica (HAESBAERT, 2004). A territorialidade evidenciada nessa área expõe a relação entre dimensão simbólica e econômica, uma vez que as práticas ali identificadas têm 
relação com os modos de vida locais e com as práticas de turismo, pesca esportiva e locação de veraneio possível ao longo da borda.

Figuras 14 e 15 - espaço de uso privado na beira do lago, com acúmulo de lixo (fig. 14), e área de plantio destinado à produção agropecuária (fig. 15).
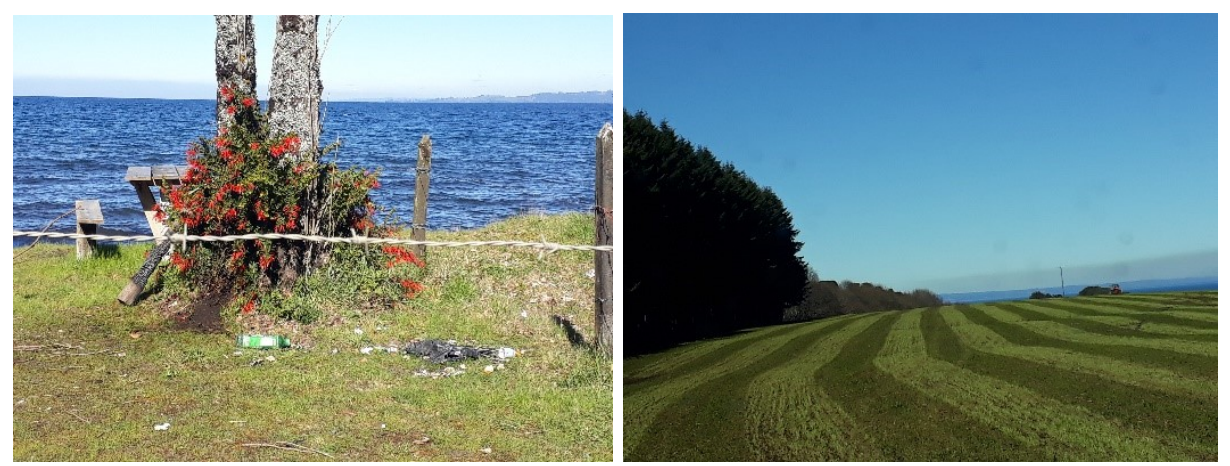

Fonte: Acervo particular da autora (setembro de 2018).

As práticas de uso do solo, portanto, são diversas e dependem do acesso aos bens, sejam eles propriedades rurais, pequenos lotes, dentre outros recursos econômicos que permitem maior influência nas atividades na borda do lago. Mesmo existindo relação com o lago, práticas que se relacionam a ele e que interferem em suas dinâmicas naturais, essa relação se estabelece muito mais diretamente pelos turistas no período do verão (que usufruem diretamente do lago) e pelas populações urbanas (que habitam áreas de encosta na borda do lago em Puerto Octay).

Os moradores das pequenas propriedades sem acesso ao lago não usufruem diretamente dele, embora contribuam para alterar as dinâmicas ecossistêmicas da borda do lago a partir de suas atividades (agropecuárias, de extração de mimbre e madeira). As áreas de propriedades privadas exercem maior influência, limitam o uso, mas da mesma forma, interferem nas dinâmicas do lago, uma vez que ali são realizadas atividades que de alguma maneira impactam e transformam a região.

Diante destes breves relatos, tomados mais no sentido de conhecimento da pesquisa desenvolvida pelos estudantes chilenos com inserção de estudantes brasileiros, ressalta-se a importância da leitura e da compreensão do espaço geográfico, elemento essencial à análise geográfica. 
O espaço geográfico, em seus recortes, não se desconecta de outros espaços em múltiplas escalaridades e não pode ser entendido sem a interação entre as dimensões histórica, social, cultural, econômica e natural. O espaço geográfico, nesse sentido, é compreendido como o espaço construído e reconstruído num movimento contínuo que se estabelece pela relação entre diferentes sujeitos na cotidianidade, com diferentes estruturas sociais, naturais e políticas, apresentando distintas funções e processos que o constituem, de acordo com a sociedade ali estabelecida.

Ter claros estes elementos contribui para o desenrolar das análises geográficas, essenciais ao desdobramento de possibilidades de educação geográfica no ensino dessa ciência, principalmente considerando o contexto escolar.

\section{ESPAÇO GEOGRÁFICO COMO CATEGORIA ESSENCIAL À ANÁLISE E À EDUCAÇÃO GEOGRÁFICA}

A investigação teve como base a categoria espaço geográfico, que serviu, posteriormente, às reflexões realizadas em grupo. Na dinâmica de discussão que se propõe com relação às análises geográficas, considera-se que essa categoria é basilar às interpretações realizadas.

Para a compreensão do espaço David Harvey (2015) menciona as ideias de Henri Lefebvre (1991 [1974]), o qual considera três dimensões: o espaço material (da experiência e percepção aberta ao toque físico e à sensação), a representação do espaço (concebido e representado) e os espaços de representação (o espaço vivido das sensações, imaginação, emoções e significados incorporados no modo como vivemos).

No trabalho de campo realizado na região Los Lagos (Chile), além de analisar o espaço material a partir da experiência a campo, foi solicitado pelo professor proponente definir suportes de interpretação. Para tanto, foi utilizada a elaboração de um croqui para representar o espaço em estudo. Esta representação do espaço e sua conceitualização possibilitaram levar ao conhecimento dos demais grupos os 
elementos em estudo e trazer à tona elementos essenciais de representação com relação ao espaço em análise.

Nesse processo, pode-se perceber o que Lefebvre considerava com relação ao espaço, a sua dimensão histórica, ou seja, o espaço geográfico é historicamente produzido pela ação dos grupos humanos à medida que se organizam política e economicamente. De acordo com o autor (2013 [1974], p. 125):

A concepção do espaço como produto social não se constituía sem dificuldades; em outras palavras, sem uma problemática em parte nova e imprevista. Não designando um "produto" qualquer, coisa ou objeto, mas um conjunto de relações, tal conceito exigia um aprofundamento das noções de produção, de produto, de suas relações.

Nesse sentido, pode-se tomar as palavras do geógrafo brasileiro Milton Santos (2006), o qual considera que o espaço é formado por um conjunto indissociável, solidário e também contraditório, de sistemas de objetos e sistemas de ações, não considerados isoladamente, mas como o quadro único no qual a história se dá. O espaço, para este autor, é hoje um sistema de objetos cada vez mais artificiais, povoado por sistemas de ações igualmente imbuídos de artificialidade, e cada vez mais tendentes a fins estranhos ao lugar e a seus habitantes.

Para a compreensão do espaço geográfico, tanto em escala local quanto em outras escalas, é necessário estabelecer relações, buscando interpretar contextos diversos que, por vezes, não são parte do cotidiano do acadêmico em formação. Por isso, o trabalho de campo é essencial na formação dos professores, pois permite que estes possam por si mesmos visualizar, sentir e perceber as características que fazem com que um recorte espacial tenha determinadas características e elementos que não estão presentes em outros, ou a outros se assemelham.

O espaço geográfico é campo de estudo profícuo, pois envolve uma diversidade de elementos que interferem nos modos de vida e são interferidos constantemente pelos grupos humanos. O espaço geográfico é construído, desconstruído, transformado num movimento contínuo que se estabelece pela relação entre diferentes sujeitos na cotidianidade, a partir de determinadas estruturas sociais, 
naturais e políticas, apresentando diferentes funções e processos que o constituem, de acordo com a sociedade ali estabelecida.

Santos (2000) afirma que a evolução que marca as etapas do processo de trabalho e das relações sociais influencia as mudanças verificadas no espaço geográfico, tanto morfologicamente, quanto do ponto de vista das funções e dos processos. É assim que as épocas se distinguem umas das outras. Nesse processo, não se pode deixar de considerar o espaço em suas distintas dimensões, definidas por Harvey (2006) como: espaço absoluto, espaço relativo e espaço relacional.

Harvey (2006) concebe o espaço absoluto como fixo, e nós registramos ou planejamos eventos dentro da moldura que o constitui. Socialmente, é o espaço da propriedade privada e de outras entidades territoriais delimitadas (como Estados, unidades administrativas, planos urbanos e grades urbanas). Para o autor, o espaço é também relativo, considerado em dois sentidos: de que há múltiplas geometrias que podemos escolher e de que o quadro espacial depende estritamente daquilo que está sendo relativizado e por quem. Porém, chama a atenção para a visão relacional do espaço, e sustenta que não há tais coisas como espaço ou tempo fora dos processos que os definem.

Deve-se, portanto, considerar no desenvolvimento do pensamento e do raciocínio geográfico do professor, o caráter relacional do espaço-tempo mais do que no espaço isoladamente. A noção relacional do espaço-tempo implica a ideia de relações internas e de influências externas que são internalizadas em processos ou coisas específicas por meio do tempo.

Compreender a relação que os diferentes sujeitos estabelecem com o espaço e entre si parte do pressuposto da capacidade de identificar aspectos que interferem no desenvolvimento social, cultural e subjetivo. Diante disso, concorda-se com Santos (1977), quando considera que nenhum dos objetos sociais tem uma tamanha imposição sobre o homem, nenhum está tão presente no cotidiano das pessoas quanto o espaço, que constitui a matéria trabalhada por excelência. Para o autor, "a casa, o lugar de trabalho, os pontos de encontro, os caminhos que unem esses 
pontos, são igualmente elementos passivos que condicionam a atividade dos homens e comandam a prática social" (SANTOS, 1977, p. 92).

Estes aspectos formaram uma característica marcante na pesquisa, pois estiveram presentes nas marcas presentes no espaço a partir das vivências cotidianas da população local, cada qual com suas especificidades em cada área analisada. Diante disso, utiliza-se as reflexões de Garrido (2005, p. 139-140) ao considerar que:

El espacio es resultado de una construcción de experiencia, al mismo tiempo que condiciona la dinámica posterior de la misma. El objeto de la geografía, se reafirma en lo significativo al mismo tiempo que en lo histórico; se amplía en su sentido material al mismo tiempo que mental; se potencia en lo fijo y en lo dinámico; se educa en relación a si mismo y a los demás.

O espaço, nesse sentido, constrói-se e se transforma dando condições de que seja pensada a dimensão das relações como possibilidade de ler o mundo em constante interação, tanto social e material, quanto subjetiva. Na construção do conhecimento, por parte dos futuros professores ou geógrafos, é necessário levar em conta essas experiências e seus desdobramentos no espaço em múltiplas relações e distintos sentidos.

Conforme Rego (2010, p. 49), no encontro geografia/educação, o objeto a ser interpretado é o espaço geográfico, enquanto que a atitude instauradora, ao convergir com o primeiro conceito (a relação meio em torno com o meio entre), elegerá os fatos cotidianos do mundo mais proximamente vivido, como fatos a serem amplamente compreendidos, relacionados entre si e com os fatos de outras escalas de análise. E sobre esses fatos que se tornam o objeto de interpretação, procurará agir, em alguma medida, modificando-os. O processo educacional, desse modo, não apenas apreende os objetos, apreende simultaneamente a capacidade de ação dos sujeitos desse processo.

O desenvolvimento da aprendizagem, a partir da análise espacial, constitui um elemento importante na geografia. Para Garrido (2005, p. 142-143):

[...] El aprendizaje se instala como construcción de significados, en tanto se amplían las capacidades para estructurar la experiencia en torno a una meta cognitiva. No hay aprendizaje, sin significados, pero tampoco hay aprendizaje 
sin una meta sobre el conocimiento. Es justamente en este sentido, que aparece como prioritario el aprendizaje del espacio, en tanto remite a metas cognitivas que el individuo considera necesarias para la construcción de su subjetividad. El aprendizaje es visto en relación a cada una de las vivencias, y por tanto se supera la idea del cumplimiento de logros en función del desarrollo biológico. Los estadios de aprendizaje se encuentran situados, y su progresión ha sido estancada cuando se ha intentado dinamizarla en base a la no autonomía.

Diante disso, a estrutura teórica, conceitual e metodológica da geografia precisa ser colocada a serviço dos processos de interpretação possíveis a partir do trabalho de campo. Essa metodologia, quando bem sistematizada e fundamentada em seus pressupostos, pode constituir-se como elemento essencial à construção de aportes para a análise geográfica de qualquer recorte espacial, levando a maior autonomia do profissional desde a formação inicial. Nesse processo, é importante trazer como suporte as construções teóricas elaboradas no âmbito da ciência geográfica e que contribuem ao olhar geográfico sobre determinado tema em estudo. Utilizando dessa estrutura pode-se, assim, construir relações, argumentar e ampliar as possibilidades de interpretação do espaço com base no desenvolvimento do raciocínio.

Ainda, propor que após essa experiência, os estudantes construam, a partir da sua construção de pensamento, um relatório de campo que alie conhecimentos teóricos e práticos, ampliando suas potencialidades de análise geográfica e construam argumentação que contribua também para qualificar a produção no campo científico da geografia e para a educação geográfica, objetivo do trabalho docente no ensino escolar de geografia.

\section{O ENSINO DA GEOGRAFIA A PARTIR DO TRABALHO DE CAMPO}

O trabalho de campo propõe, ao longo da formação acadêmica, que os estudantes inicialmente acompanhem o desenvolvimento do raciocínio do professor que o propõe e, mais adiante, nas etapas finais do curso, insiram-se a campo como investigadores e construtores de novos conhecimentos, tendo como suporte os conhecimentos da ciência geográfica que amparam a construção do seu pensamento 
de professor e de suas capacidades de argumentação, reflexão e problematização. Estas capacidades convergem para o desdobramento de um raciocínio geográfico que possibilita realizar análises geográficas.

Construir conhecimentos geográficos com base nas atividades de campo tem sido uma possibilidade, uma vez que se constitui na observação sistematizada e na busca por informações e dados necessários à análise geográfica. Pensar a geografia a partir da observação do espaço geográfico, para além do espaço vivido cotidianamente, expande o olhar docente e contribui, em grande medida, para propor, na escola, outras possibilidades de análise e interpretação. Os procedimentos metodológicos, já mencionados, são essenciais ao desenvolvimento dessa possibilidade.

Para que isso seja viabilizado, o trabalho docente supõe profissionais preparados para a condução desse processo, que sejam comprometidos e atentos às intensas transformações do mundo e da educação no contexto contemporâneo. Conforme Martija e Silva (2013), “los docentes son una clave para una enseñanza renovada de la Geografía", o que implica em levar em consideração algunas questões essenciais no ensino que propõe e, no contexto desta escrita, nas propostas que realizam em trabalhos de campo.

De acordo com estes autores (2013), as perguntas a serem consideradas são: “¿Qué tendrían que aprender los estudiantes al estudiar Geografía? [...] ¿Cuáles son las formas y medios utilizados en el aprendizaje de la Geografía? [...] ¿Cuál es la Geografía que se enseña y se aprende? (MARTIJA E SILVA, 2013, p. 158). Estes aspectos servem também ao planejamento das atividades de campo, haja vista que, ao serem organizadas pelo professor proponente, contribuem para pensar tanto a formação dos professores para a educação básica, quanto no que concerne à formação de geógrafos, embora existam aspectos específicos a serem considerados em cada processo de formação.

Contribuem, ainda, para que os professores em formação construam, pela relação teoria e prática, seus modos de pensar e raciocinar geograficamente, que 
favoreçam a construção de argumentos e a problematização do ensino de geografia, ao qual estarão preparados a atuar.

Esse processo de construção profissional, a partir das experiências de campo, se constitui em distintas etapas ao longo da formação acadêmica e tende a viabilizar análises e interpretações que possam significar o ensino de geografia, contribuindo assim para que construam com os estudantes o movimento de educação geográfica.

\section{CONSIDERAÇÕES FINAIS}

O que se espera, ao concluir um trabalho de campo, é que o professor em formação acadêmica retorne com um conhecimento mais amplo da dimensão geográfica e mais atento às diversas realidades, situações e dinâmicas que ocorrem no espaço. Por meio da observação e da reflexão sobre diferentes relações sociais, políticas, econômicas, culturais, que dão sentido ao espaço, os acadêmicos podem relacionar elementos que complexifiquem ainda mais o seu pensamento geográfico de professor e potencializem sua capacidade de raciocinar geograficamente.

Martija e Silva (2013, p. 152), consideram que "[os trabalhos de campo] fuera de los requerimentos administrativos que pueda representar, este tipo de estrategia involucra una alta complejidad de razonamiento, por lo tanto contribuye a aprendizajes más relevantes". É uma metodologia que possibilita tanto a formação do professor de geografia e do geógrafo (no caso da experiência proposta pelo curso de bacharelado em Geografia da UAHC), quanto construir meios para ensinar a geografia escolar.

Os trabalhos de campo têm importância fundamental na formação profissional para construir aportes à leitura, interpretação e compreensão das relações sociedade-natureza presentes no espaço e para a sistematização dos dados em uma investigação. Nesse viés, a análise geográfica de determinado espaço potencializa o 
pensamento e o raciocínio geográfico, contribuindo para a construção de elementos basilares à educação geográfica.

\section{REFERÊNCIAS}

CALLAI, Helena C. Entrevista. Revista Brasileira de Educação em Geografia, Campinas, v. 6, n. 11, p. 6-20, jan./jun. 2016.

CALLAI, Helena C. Estudar o lugar para compreender o mundo. In: CASTROGIOVANNI, A. C. (Org.). Ensino de geografia: práticas e textualizações no cotidiano. Porto Alegre: Mediação, p. 71-114, 2012.

CALLAI, Helena C. A formação do profissional da geografia. Ijuí: Ed. Unijuí, 1999.

CASTELLAR, Sonia M. Vanzela. Educação geográfica: a psicogenética e o conhecimento escolar. Cad. Cedes, Campinas, vol. 25, n. 66, p. 209-225, maio/ago. 2005.

CAVALCANTI, Lana de S. A geografia escolar e a cidade: ensaios sobre o ensino de Geografia para a vida urbana cotidiana. Campinas, SP: Papirus, 2008.

CHILE. Conselho Nacional de la Cultura y las Artes. Portadores de patrones especiales $y$ tipos constructivos. Disponível em: http://www.portadores.uc.cl/destinos_llanquihue_oriente_eng.html. Acesso em setembro, 2018.

COPATTI, Carina. Pensamento pedagógico geográfico e autonomia docente na relação com o livro didático: percursos para a educação geográfica. (Tese) Pósgraduação em Educação nas Ciências. Universidade Regional do Noroeste do Estado do Rio Grande do Sul. Ijuí, 2019.

CORREA, R. L. Trabalho de campo e globalização. Colóquio O discurso Geográfico na Aurora do século XXI. Programa de pós-graduação em Geografia - UFSC. Florianópolis: 27-29 de novembro de 1996.

GARRIDO, M. El Espacio por Aprender, el Mismo que Enseñar. Las Urgencias de la Educación Geográfica. Cedes Campinas, v. 25, n. 66, p. 137-163, 2005.

HARVEY, David. O espaço como palavra-chave [2006]. Em pauta, Rio de Janeiro, n. 35, v. 13, p. 126-152, 2015.

LEFEBVRE, Henri. Prefácio - A produção do espaço. 1974. Estudos avançados, n. 27 (79), 2013. 
MARTIJA, Andoni Arenas. SILVA, Víctor Salinas. Giros en la Educación Geográfica: renovación de lo geográfico y lo educativo. Revista de Geografía Norte Grande, n. 56: p. 143-162, 2013.

REGO, Nelson. Geração de ambiências: três conceitos articuladores. Educação, Porto Alegre, v. 33, n. 1, p. 46-53, jan./abr. 2010.

SANTOS, Milton. Metamorfoses do espaço habitado. 4.ed. São Paulo: Hucitec, 1996.

SUERTEGARAY, Dirce M. Notas sobre epistemologia da Geografia. Cadernos Geográficos. Florianópolis, n. 12, maio, 2005.

TOMITA, Luiza M. S. Trabalho de campo como instrumento de ensino em Geografia. Geografia, Londrina, v. 8, n. 1, p. 13-15, jan./ jun. 1999.

' O presente artigo resulta de reflexões originadas de uma experiência de estudos no Chile, por meio do intercâmbio fruto do convênio entre o Programa de Pós-Graduação em Educação nas Ciências e a Universidade Acadêmica de Humanismo Cristiano-UAHC, mediado na Unijuí pela professora Helena C. Callai e na UAHC - Chile pelo professor Marcelo Garrido Pereira. Foram realizadas no Chile duas atividades principais: na Universidade Católica de Valparaíso, sob coordenação do professor Andoni Arenas Martija e em atividades de campo, coordenadas pelo professor Marcelo Garrido Pereira da Universidade Acadêmica de Humanismo Cristiano-UAHC.

ii Dentre as atividades foi possível interagir com professores e estudantes, participando de grupo de estudo em Valparaíso, conhecendo a dinâmica urbana de Santiago e Valparaíso e compreendendo aspectos da dinâmica socioespacial da região de estudo - Los Lagos, onde estiveram concentradas as atividades de trabalho de campo realizadas nessa experiência.

iii Esquema composto por um modelo de análise com multicritérios, o qual constitui um elemento a ser utilizado, construído e transformado no decorrer do trabalho de campo. 